\title{
Immunohistochemical and molecular detection of equine herpesvirus 1 in Uruguay
}

\author{
C. Easton ${ }^{[1]}$, N.A. Fuentealba ${ }^{(3,4)}$, C. Paullier ${ }^{(1)}$, P. Alonzo ${ }^{(1)}, \mathrm{J}$. Carluccio ${ }^{[2]}$ \\ \& C.M. Galosi $\mid 3,5)^{*}$
}

\begin{abstract}
(1) Department of Pathobiology, Veterinary Laboratories Division (DILAVE) 'Miguel C. Rubino', General Direction of Livestock Services of the Ministry of Livestock, Agriculture and Fisheries (MGAP). Ruta 8 Brig. Gral. JA Lavalleja, Km.17.500, Montevideo, Uruguay

(2) Department of Equine Clinic, Faculty of Veterinary Medicine, University of the Republic, A Lasplaces 1550 , Montevideo, Uruguay

(3) Department of Virology, Faculty of Veterinary Sciences, National University of La Plata, 60 y 118, CC296,

1900 La Plata, Buenos Aires, Argentina

(4) National Research Council (CONICET), Av. Rivadavia 1917, C1033 AAJ, Buenos Aires, Argentina

(5) Scientific Research Commission (CIC), 10 y 526, 1900 La Plata, Buenos Aires, Argentina
\end{abstract}

"Corresponding author: cmgalosi@fcr.unlp.edu.ar; cmgalosi@yahoo.com

Submitted for publication: 24 July 2008

Accepted for publication: 7 May 2009

\begin{abstract}
Summary
Equine herpesvirus 1 (EHV-1) is a major cause of epidemic abortion, neonatal mortality, respiratory disease and neurological disorders in horses. In South America, the virus has been isolated in Brazil, Argentina and Colombia. In Chile pathological findings from one aborted foetus have been reported, and in Uruguay only serological data about EHV-1 activity have been found. Some pathological findings were reported in Uruguay several years ago, but these data have never been officially confirmed. The present work describes the relevant findings of a study of EHV-1 infections in the Uruguayan equine population using polymerase chain reaction (PCR) and histological and immunohistochemical analysis techniques. The sequence analysis of a portion of the glycoprotein $\mathrm{C}$ gene amplified by PCR confirmed EHV-1 activity. The real-time PCR revealed the association of the virus with the non-neuropathogenic genotype. This study describes for the first time the immunohistochemical and molecular detection of EHV-1 in Uruguay.
\end{abstract}

\section{Keywords}

Equine herpesvirus 1 - Foetal tissues - Immunohistochemistry - Molecular characterisation - Molecular detection - Uruguay.

\section{Introduction}

Equine herpesvirus 1 (EHV-1) is a major cause of epidemic abortion, neonatal mortality, respiratory disease and neurological disorders in horses. Infection by this virus is a serious economic problem in the horse industry worldwide, especially on breeding farms $(3,6,11)$. The severity of the disease resulting from EHV-l infection is likely to be influenced by a number of factors, including the age and physical condition of the host, whether the infection is primary, secondary or a reactivation of a latent virus, the immune status of the host and the virulence of the strain involved. Recent experimental studies have identified a single nucleotide polymorphism $\left(A_{225+} / G_{2254}\right)$ within the EHV-l gene encoding the viral deoxyribonucleic acid (DNA) polymerase (open reading frame-30 [ORF-30]) that is highly associated with the viral attribute of neuropathogenicity in horses (10). The pathogenesis of abortion induced by this virus is still not fully understood. After airborne infection, the virus replicates in the nasal mucosa and via infected mononuclear leucocytes it reaches various organs, including the endometrium. Severe infarction of the 
endometrium produced by vasculitis and thrombi may lead to detachment of the placenta and abortion, even before the virus reaches the foetus. In cases with milder and circumscribed lesions, infarction causes only slight tissue damage, the abortion is not immediately produced, the virus reaches the foetus via the circulation and the aborted foetus is virologically positive (16).

In South America, the first isolates from an equine foetus aborted due to EHV-l were reported in Brazil and Argentina in 1966 and 1979 respectively (7, 9). Chile reported pathological lesions in an aborted foetus in 1998 (13) and Peru and Paraguay reported the presence of respiratory clinical signs and abortions in 2001, although these data were not officially declared. In addition, the virus has been isolated in Venezuela (2001) and Colombia (2002) (5, 14).

In Uruguay, only sporadic serological data about EHV-1 activity have been reported (4). The virus has not yet been isolated and information on the pathological findings was found several years ago but not published. In addition, neurological disease associated with EHV-l has never been reported. However, the immunisation of horses on some farms has been implemented with an inactivated vaccine.

Routine diagnostic methods to confirm EHV-1 infection are virus isolation (VI) and direct immunofluorescence, which detects viral antigens in fresh foetal tissues. Immunohistochemical (IHC) methods to detect antigens in formalin-fixed tissues and polymerase chain reaction (PCR) have been useful in diagnostic laboratory settings $(12,14)$. In addition, Allen has developed a real-time PCR for rapid diagnosis of neuropathogenic strains (1).

This study describes, for the first time, the confirmatory pathological, immunohistochemical and molecular findings about EHV-1 activity among horses in Uruguay.

\section{Materials and methods}

\section{Samples}

Samples were taken from a case of equine abortion of a nine-month-old foetus that arrived at the Laboratory of the Department of Pathobiology, Veterinary Laboratories Division 'M.C. Rubino', Montevideo, Uruguay. According to standard procedures, necropsy was carried out and samples were taken from the lung, liver, kidney, spleen, heart, central nervous system, thymus and placenta. All the samples were directly fixed by immersion in $10 \%$ neutral buffered formalin (pH 7.2 to $\mathrm{pH} \mathrm{7.4)}$ for $72 \mathrm{~h}$ and embedded in paraffin wax at $56^{\circ} \mathrm{C}$ to $59^{\circ} \mathrm{C}$.

\section{Histological and immunocytochemical analysis}

Sections of $5 \mu \mathrm{m}$ of paraffin-embedded tissues were stained with haematoxylin and eosin. Some sections of liver and lungs were processed for IHC analysis. The slides were deparaffinised by immersion in xylene and rehydrated with graded alcohols. After blocking endogenous peroxidase activities with $1 \% \mathrm{H}_{2} \mathrm{O}_{2}$ in methanol, non-specific background staining was reduced by covering the tissue sections with two alternative blocking solutions: skim milk ( $1 \%$ to $5 \%$ ) in phosphate-buffered saline (PBS) or bovine serum albumin $(0.5 \%$ or $1 \%)$ in PBS. The sections were then washed with PBS, incubated for $30 \mathrm{~min}$ with 1:2000 monoclonal antibody (Ab) specific to EHV-1 (supplied by Dr Makamoto Haritani, National Institute of Animal Health, Tsukuba, Japan) and revealed with a commercial kit (DakoCytomation LSAB 2 Systems, DakoCytomation, Carpintería, CA 93013, United States of America [USA]). The slides were then counterstained with aqueous haematoxylin. Negative controls (liver and lungs from a healthy, EHV-1-free horse) were included.

\section{Polymerase chain reaction}

Sections of $5 \mu \mathrm{m}$ were deparaffinised in a tube by immersion in xylene at $37^{\circ} \mathrm{C}$ for $30 \mathrm{~min}$ and then centrifuged at $3,000 \mathrm{~g}$. The same procedure was repeated with $100 \%$ and $95 \%$ ethanol. Pellets of samples were digested for $3 \mathrm{~h}$ at $50^{\circ} \mathrm{C}$ in TEN buffer ( $1 \mathrm{M}$ Tris, $0.05 \mathrm{M}$ ethylenediaminetetra-acetic acid and $0.3 \mathrm{M}$ sodium chloride) containing $10 \%$ sodium dodecyl sulphate and $0.1 \mathrm{mg}$ of proteinase $\mathrm{K} / \mathrm{ml}$. Then, $1 \mathrm{ml}$ of $6 \mathrm{M}$ sodium chloride was added and, after shaking, ethanol precipitation was carried out. Total DNAs were suspended in distilled water. At the first step, the amplification was performed according to published methods and using a pair of specific oligonucleotide primers derived from the EHV-1 glycoprotein C gene region (8). Deoxyribonucleic acid from EHV-1 and EHV-4 was used as a control. The PCR products were purified using a gel extraction kit (Wizard ${ }^{\circledR}$ SV Gel and PCR Clean Up, Promega) and sequenced (Biotechnology Resource Center, University of Cornell, Ithaca, USA). The sequences were analysed and compared with the homologous sequence from the EHV-I reference Ab4 strain (GenBank, access number AY665713) using Clustal X version 1.92 software.

At the second step, a real-time PCR was performed according to the methodology previously described by Allen and using specific primers that amplify a 145 base pair (bp) fragment of the ORF-30 of EHV-1 (1). The reaction was carried out by researchers of the National Institute of Agricultural Technology (INTA, Castelar, Buenos Aires Province, Argentina) using an ABI 7500 Fast Real-Time PCR system (Applied Biosystems, Foster City, CA, USA) 


\section{Results}

Histological examination of the lungs revealed disseminated foci of fibrinous alveolar exudates with foci of necrosis in the bronchiolar epithelium associated with intranuclear inclusion bodies (IC) as well as cell infiltration into the lung parenchyma. The liver showed multifocal hepatocellular necrosis and degeneration, with moderate infiltration by macrophages. A few IC were seen in the hepatocytes and Kupffer cells around the necrotic areas. No lesions were observed in the other samples studied. A positive staining reaction indicated binding of $\mathrm{Ab}$ to sites of the EHV-l antigen, producing a deep-brown colour which contrasted sharply with the blue counterstain of the tissues. This positive IHC stain was observed associated with necrotic foci in the liver (Fig. 1), as well as with the broncho-alveolar epithelial cells and alveolar macrophages of the lungs (Fig. 2). No non-specific brown staining was observed when $5 \%$ skim milk in PBS or $1 \%$ bovine serum

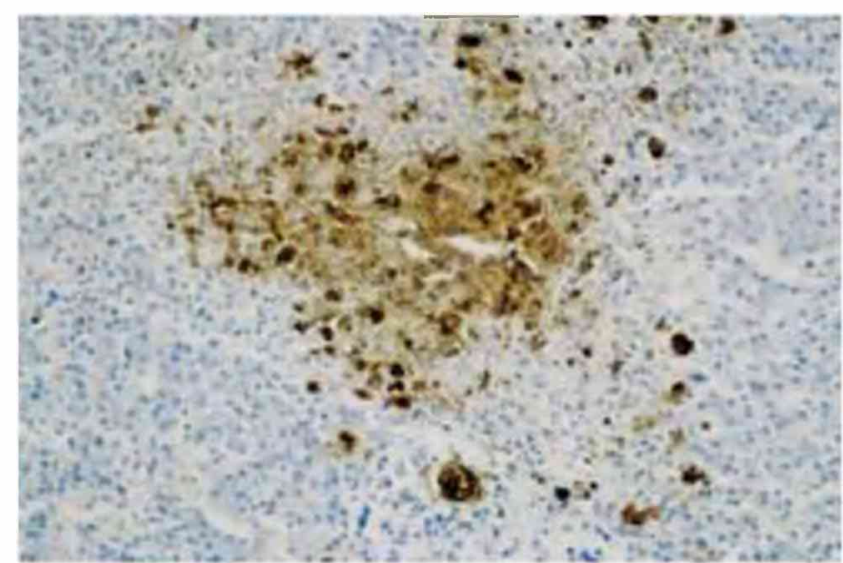

Fig. 1

Equine foetal liver infected with equine herpesvirus 1

Necrotic focus with positive reaction (immunohistochemistry $400 \times$ )

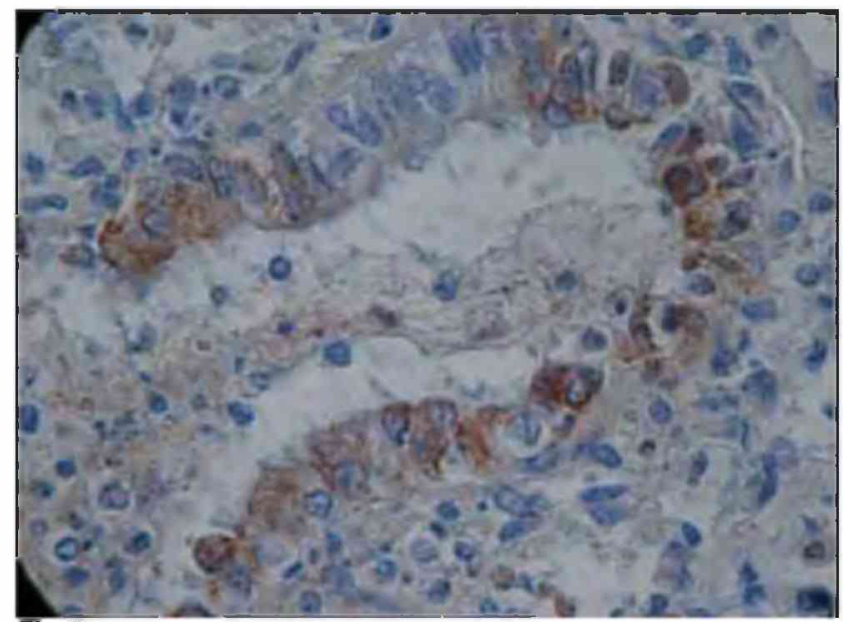

Fig. 2

Equine foetal lung infected with equine herpesvirus 1

Bronchiolar epithelium and alveolar macrophages with positive reaction (immunohistochemistry $1000 \times$ ) albumin in PBS was used. A 489 489-bp band amplified by direct PCR was observed from samples prepared from lung and liver tissues. No amplification was detected for EHV-4 under the conditions described here (Fig. 3). Both sequences analysed showed identity with the corresponding sequence of the EHV-l reference $\mathrm{Ab} 4$ strain. Real-time PCR revealed association of the virus with the non-neuropathogenic genotype (A2254).

\section{Discussion}

For the diagnosis of EHV-l infection associated with abortion in mares, conventional VI is often considered the 'gold standard' technique (16). Virus isolation is highly sensitive, but the technique requires highly trained technicians to perform the test, and it can take several days, or sometimes weeks, to complete. Moreover, the samples for VI need to be maintained at an optimal temperature. In this study, the samples could not be processed for VI.

The IHC test is a sensitive, specific test for EHV-1, but has not always given $100 \%$ correlation with VI results (15). However, in the present work pathological changes and IHC analysis showed with certainty the presence of the antigen in tissues from the aborted foetus.

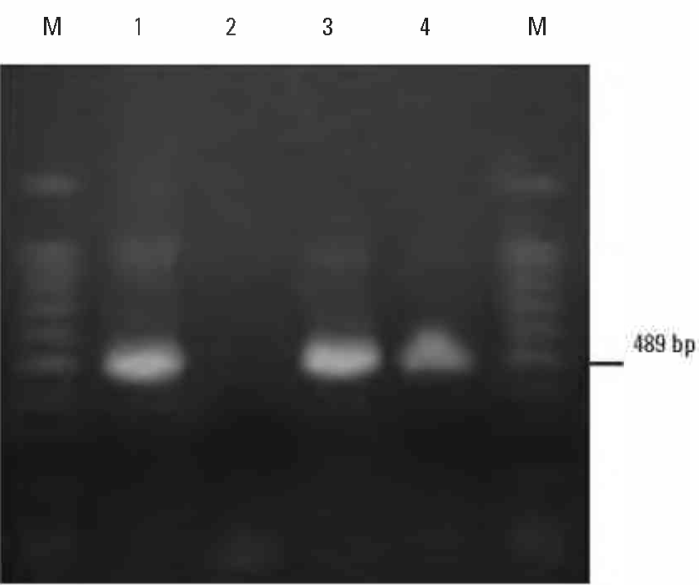

Fig. 3

Electrophoresis of polymerase chain reaction products from lung and liver foetal tissues amplified with primer pair specific for equine herpesvirus 1 glycoprotein C

The number on the right denotes the number of base pairs (bp) for positive amplification Lane M: molecular weight markers (100 bp to $1500 \mathrm{bp}$ ) Lane 1: positive control (DNA of Japanese HH1 reference strain of $E H V-1)$

Lane 2: negative control (DNA of Japanese TH20 reference strain of EHV-4)

Lanes 3 and 4: positive amplification from lung and liver, respectively 
Direct PCR was a valuable and powerful adjunct to confirm EHV-1 diagnosis. In addition, the sequence of a portion of the glycoprotein $C$ gene amplified by PCR confirmed EHV-1 activity. Furthermore, real-time PCR reaffirmed the first result and revealed that the strain was not associated with the neuropathogenic genotype $\left(\mathrm{G}_{225 t}\right)$.

Reports of EHV-1 neurological disease have been increasing in frequency and severity, particularly in recent years in the USA and Europe (2). Countries of South America that have reported EHV-1 activity among their equine populations have reported only respiratory disease and abortion; there are no references to neurological disease caused by EHV-1. Only recent research carried out in Colombia into EHV-1 DNA detection in peripheral blood mononuclear cells by PCR, and the subsequent study of the gene sequence that encodes the viral DNA polymerase, showed that the circulating amplified viral strain was not neuropathogenic (14).

Recent studies in Argentina by real-time PCR have revealed that $7 \%$ of the strains isolated in the country between 1996 and 2008 from cases of abortions and neurological disease were associated with the neuropathogenic genotype $\left(G_{225+}\right)$ (data not yet published). This is a very important finding because the main equine activity is in Buenos Aires province, geographically very close to Uruguay. This is a relevant epidemiological situation that emphasises the need to isolate the virus from Uruguayan equines and to know which EHV-l genotypes are circulating. On the other hand, although the virus has not been isolated yet, it is important to regularly re-vaccinate pregnant mares and other horses on breeding farms to reduce the potential risk of abortion storm and neurological disease.

The results presented here constitute the first official report of abortion produced by EHV-l among horses from the Uruguayan equine population.

\section{Acknowledgements}

This study was partially supported by a grant from the Scientific Research Commission (CIC), Buenos Aires Province (Res. 673/06). The authors acknowledge with gratitude the valuable assistance in real-time PCR technique of MV Aldana Vissani and María Barrandeguy (National Institute of Agricultural Technology, Castelar, Buenos Aires, Argentina).

\title{
Détection immunohistochimique et caractérisation moléculaire de I'herpèsvirus équin de type 1 en Uruguay
}

\author{
C. Easton, N.A. Fuentealba, C. Paullier, P. Alonzo, J. Carluccio \& \\ C.M. Galosi
}

\section{Résumé}

L'herpèsvirus équin de type 1 (EHV-1) est un virus important qui provoque chez le cheval des avortements infectieux, une mortalité néonatale, des pathologies respiratoires et des troubles neurologiques. En Amérique du Sud, le virus a été isolé au Brésil, en Argentine et en Colombie. Au Chili, des lésions pathologiques ont été signalées chez un fotus avorté ; en Uruguay, l'activité du virus EHV-1 n'avait été jusqu'à présent décelée que lors d'analyses sérologiques. II y a quelques années, des cas de lésions ont bien été signalés mais n'ont jamais été officiellement confirmés. Les auteurs décrivent les résultats d'une étude sur l'infection par le virus EHV-1 dans la population équine d'Uruguay, basée sur la technique d'amplification en chaîne par polymérase (PCR) et sur des analyses 
histologiques et immunohistochimiques. L'analyse de séquence d'un fragment du gène de la glycoprotéine $C$ amplifié par PCR a confirmé l'activité du virus EHV-1. L'amplification par PCR en temps réel a révélé que la souche virale appartenait au génotype non neuropathogénique. II s'agit de la première détection immunohistochimique et moléculaire du virus EHV-1 en Uruguay.

\title{
Mots-clés
}

Caractérisation moléculaire - Détection moléculaire - Herpèsvirus équin de type 1 Immunohistochimie - Tissus de fœetus - Uruguay.

\section{Detección inmunohistoquímica y molecular del herpesvirus equino 1 en el Uruguay}

\author{
C. Easton, N.A. Fuentealba, C. Paullier, P. Alonzo, J. Carluccio \\ \& C.M. Galosi
}

\section{Resumen}

El herpesvirus equino 1 (EHV-1) es una de las principales causas de aborto epidémico, mortalidad neonatal, enfermedad respiratoria y trastornos neurológicos en el caballo. En Sudamérica, este virus ha sido aislado en Brasil, Argentina y Colombia. En Chile se han descripto signos patológicos en un feto abortado, y en el Uruguay sólo se han comunicado datos serológicas que revelan la actividad del EHV -1. Hace varios años se describieron en el Uruguay signos patológicos, aunque ello nunca fue confirmado oficialmente. En este trabajo se describen las conclusiones obtenidas de un estudio sobre infección por EHV-1 en la población equina uruguaya, para el cual se utilizó la reacción en cadena de la polimerasa (PCR) y técnicas de análisis histológico e inmunohistoquímico. El análisis de la secuencia de un fragmento del gen de la glicoproteína $C$ amplificado por PCR confirmó la existencia de actividad del EHV-1. La PCR en tiempo real corroboró la asociación del virus con el genotipo no neuropatógeno. Este estudio describe la primera detección molecular e inmunohistoquímica del EHV-1 realizada en el Uruguay.

\section{Palabras clave}

Caracterización molecular - Detección molecular - Herpesvirus equino 1 Inmunohistoquímica - Tejidos fetales - Uruguay.

\section{References}

1. Allen G.P. (2007). - Development of a real-time polymerase chain reaction assay for rapid diagnosis of neuropathogenic strains of equine herpesvirus-1. J. vet. diagn. Invest., $19,69-72$

2. Allen G.P., Bolin D.C., Bryant U., Carter C.N., Giles R.C., Harrison L.R., Hong C.B., Jackson C.B., Poonacha K., Wharton R. \& Williams N.M. (2008). - Prevalence of latent, neuropathogenic equine herpesvirus- 1 in the thoroughbred broodmare population of central Kentucky. Equine vet. J., $40(2), 105-110$
3. Allen G.P. \& Bryans J.T. (1986). - Molecular epizootiology, pathogenesis, and prophylaxis of equine herpesvirus-1 infections. Prog. vet. Microbiol. Immunol., 2, 78-144.

4. Alonzo P., Reolon E., Piaggio J. \& Maisonnave J. (2005). Prueba de inmunogenicidad en vacunas para rinoneumonitis equina. In Proc. 12th International Symposium of the World Association of Veterinary Laboratory Diagnosticians and 7th OIE Seminar on Biotechnology, 16-19 November, Montevideo, Uruguay. 
5. Cano A., Galosi C.M., Martin Ocampos G.P., Ramirez G.C., Vera V.J., Villamil L.C. \& Chaparro J.J. (2008). - Equine herpesvirus 1: characterisation of the first strain isolated in Colombia. Rev. sci. tech. Off. int. Epiz, 27 (3), 893-897.

6. Crabb B.S. \& Studdert M.J. (1995). - Equine herpesviruses 4 (equine rhinopneumonitis virus) and 1 (equine abortion virus). Adv. Virus Res, , 45, 153-190.

7. Etcheverrigaray M.E., Oliva G.A., Gonzalez E.T., Nosetto E.O. \& Martín A.A. (1982). - Comportamiento de una cepa de HVE-1 aislada de un feto abortado. Rev. mil. Vet., $30,138-139$

8. Galosi C.M., Vila Roza M.V., Oliva G.A., Pecoraro M.R., Echeverria M.G., Corva S. \& Etcheverrigaray M.E. (2001). A polymerase chain reaction for detection of equine herpesvirus-l in routine diagnostic submissions of tissues from aborted foetuses. J. vet. Med. B., 48 (5), 341-346.

9. Nilsson M.R \& Correa W.M. (1966). - Isolamento do vírus de aborto equinino no Estado de Sao Paulo. Arq. Inst. Biol. (Sao Paulo), 33, 23-25.

10. Nugent J., Burch-Machin I., Smith K.C., Mumford J.A., Swann Z., Newton J.R., Bowden R.J., Allen G.P. \& Davis-Poynter N. (2006). - Analysis of equid herpesvirus 1 strain variation reveals a point mutation of the DNA polymerase strongly associated with neuropathogenic versus non-neuropathogenic disease outbreaks. J. Virol, $80,4047-4060$.
11. Patel J.R. \& Heldens J. (2005). - Equine herpesviruses 1 (EHV-1) and 4 (EHV-4) epidemiology, disease and immunoprophylaxis: a brief review. Vet J., 170 (1), 14-23.

12. Rimstad E. \& Evensen O. (1993). - The identification of equid herpesvirus 1 in paraffin-embedded tissues from aborted foetuses by polymerase chain reaction and immunohistochemistry. J, vet. diagn. Invest, 5 (2), 174-183.

13. Ruiz A., Quezada M., Gomez-Villamandos J., Berrios P. \& Sierra A. (1998). - Aborto viral equino. Descripción anatomopatológica de dos casos ocurridos en la VIII Región, Chile. Arch. Med. vet. (Chile), 30 (1), 161-168.

14. Ruiz Saenz J., Goez Y. \& Lopez Herrera A. (2008). - Equine herpesvirus 1 and 4 DNA detection in peripheral blood mononuclear cells and trigeminal ganglion of equines: infection, latency and approximation to neuropathogenesis of the strain. Rev. Colomb. Cien. pec., 21 (3), 372-386.

15. Schultheiss P.C., Collins J.K. \& Carman J. (1993), - Use of an immunoperoxidase technique to detect equine herpesvirus-1 antigen in formalin-fixed paraffin-embedded equine foetal tissues. J. vet. diagn. Invest., 5 (1), 12-15.

16. World Organisation for Animal Health (OIE) (2004). Equine rhinopneumonia, Chapter 2.5.7. In Manual of diagnostic tests and vaccines for terrestrial animals, OIE, Paris, 707-716. Available at: www.oie.int/esp/normes/ mmanual/A_00085. htm 